\title{
TECTONOSTRATIGRAPHIC TERRANB ANALYSIS OF NEW BRUNSWICK
}

\author{
L.R. PYffe \\ New Brunswick Department of Natural Resources and Energy \\ P.O. Box 6000, Preder1cton, New Brunsw1ck E3B 5HI \\ A. Fricker* \\ Geological Survey of Canada, Atlantic Geoscience Centre \\ Bedford Institute of Oceanography \\ P.O. Box 1006, Dartmouth, Nova Scot1a B2Y $4 A 2$ \\ Date Rece1ved January 23, 1987 \\ Date Accepted June 5, 1987
}

\begin{abstract}
The contents of a computerized lexicon database are displayed in the form of a range chart that demonstrates the spatial and temporal relationships of lithostratigraphic units to tectonostratigraphic terranes of New Brunswick. The chart provides a reference basis from which to derive the accretionary history of these terranes.

The tectonostratigraphic zonation of New Brunswick 1s based upon the uniqueness of the pre-Taconian stratigraphy within each fault-bounded terrane. From northwest to southeast. the following terranes and cover sequences are recognized: Matapedia Cover. Blmtree Terrane. Miramich1 Terrane. Fredericton Cover, St. Croix Terrane, Mascarene Terrane, and Avalonian Terrane.

Overstepping of the Matapedia Cover Sequence indicates that the Elmtree and Miramichi terranes were docked with the North American craton by the Late Ordovician to Barly Silurian. The presence of a similar early Paleozolc strat1graphy. tectonic style and major S1lurian unconformity in the St. Crolx Terrane suggests that 1t had become docked to the Miramichi Terrane prior to this subduction-related Taconian event.

Detritus and a simllar fauna in the cover rocks of the St. Croix Terrane provide evidence that 1t was docked to the Mascarene Terrane by the Late Silurian. This docking coincided with the Salinic disturbance in northern New Brunswick where $1 \mathrm{t}$ is marked by an unconformity on the northwestern margin of the Miramich1 Terrane and by coarse clastic sedimentation and local deformation within the Matapedia Cover Sequence. Detritus links the Mascarene and Avalonian terranes by the Late Devonian. The Salinic disturbance and culminating Acadian orogeny are interpreted to be the result of transcurrent convergence that accreted the Mascarene and Avalonian terranes to North America.
\end{abstract}

On rend le contenu d'un lexique informatisé sous forme d'un tableau qui démontre les relations spatiales et temporelles entre les unités lithostratigraphiques et les laniéres tectonostratigraphiques présentes au NouveauBrunswick. Ce tableau sert de pivot pour dériver 1'histoire de 1'accrétion de ces lanières.

On base le zonage tectonostratigraphique du Nouveau-Brunswick sur le caractère unique de la stratigraphie prétaconienne au sein de chaque lanière. Du nord-ouest au sud-est. on reconnaft les lanières et les séquences de couverture suivantes: la Couverture de Matapédia, les lanières d'Blmtree et de Miramich1, la Couverture de Fredericton ainsi que les lenières de St. Cro1x. Mascarene et d'Avalon.

Leur emplétement par la Séquence de Couverture de Matapédia démontre qu'à l'Ordovicien tardif, ou à l'Eosilurien, les lanières d'Elmtree et de Miramich1 se sont déjà juxtaposées au craton nord-américain. La similarité de leurs stratigraphies éopaléozoïques et de leurs styles tectoniques, ainsi qu'une discordance silurienne importante dans la Lanière de St. Croix suggère 1'accolement de cette derniere sur la Lanière de Miramichi avant cet événement taconien relié à une subduction.

La preuve que la Lanière de St. Crolx s'est déjà accolée à la Lanière de Mascarene au Silurien tardif réside dans les faciès détritiques et une faune semblable dans les roches de couverture de cette première. Cette juxtaposition coïncide avec le tumulte salinique au Nouveau-Brunswick septentrional où elle se marque par une discordance sur la marge nord-ouest de la Lanjère de Miranichi adnsi que par un épandage détritique grossier et une déformation locale au sein de la Séquence de Couverture de Matapédia. Un lien détritique s'établit entre les lanières de Mascarene et d'Avalon avant le Dévonien tardif. On interprète le tumulte salinique et le paroxysme de l'orogénie acadienne comme résultant d'un coulissage convergent qui a accrétionné les lanières de Mascarene et d'Avalon sur l'Amérique du Nord.

[Traduit par le fournal]

\section{INTRODUCTION}

New concepts in the earth sciences have been developed recently that greatly ald in unravelling the geologic history of an orogen. Tectonostrat1graphic zones that earlier were defined on the basis of 11thofacies and tectonic styles are now being re-evaluated using the model of accretion of terranes, which provides more specific criterla for

*GSC Contribution No. 53886 their recognition and definition (Jones et al., 1983).

The first part of this paper discusses some of the principles and problems related to the establishment of geotectonic nomenclature. The detalled stratigraphic information compiled in Volume 6, Atlantic Region, Lexicon of Canadian Stratigraphy (Williams et al., 1985) is then applied specifically to the evaluation of the tectonic zonation of New Brunswick. Since information on formal 11thostratigraphic and 1ithodemic 
(p1utonic, metamorphic) units had been assembled in a computer database, it was an easy matter to construct correlation charts that could be grouped into the previously established tectonostratigraphic framework of New Brunswick. In the second part of the paper, these charts are used as a basis to reconstruct the accretionary history of New Brunswick in terms of terrane concepts.

\section{TERRANE CONCEPTS}

The fundamental tectonic division is the tectonostratigraphic terrane, which is defined as a faultbounded geologic entity of regional extent characterized by a distinctive geologic history (Jones et al., 1983). This definition is similar to that for tectonostratigraphic zone (see Spencer, 1974) except that terrane boundaries are delimited by faults and the terranes, themselves, are considered to be allochthonous unless proven otherwise.

Tectonostratigraphic zones represent regional paleogeographic features such as a craton, and remnants of continental margin, island arc and ophlolitic assemblages that commoniy trend paralle1 to the length of an orogenic belt (see Williams, 1979; Zen, 1983). The paleogeographic setting of each zone is determined from an examination of the stratigraphy and deformational history of its constituent 11thogenetic elements, such as basement and cover rocks. These tectonic elements are composed of the groups, formations, suites, and complexes that comprise the 11thostratigraphy of a zone.

The fundamental tenet of the terrane concept is that orogens develop by accretion of allochthonous terranes along the continental margin. Thus, cratons and autochthonous continental margins are generally not considered to constitute a terrane (see Williams and Hatcher, 1982). Accretion of terranes in the general case takes place by oblique subduction and obduction. Terranes are sald to be "docked" upon initial collison, but relative displacement may continue by transcurrent motion. Terranes finally become "welded" together when their mutual faulted boundary becomes inactive. Timing of accretion can be constrained by determining whether 1ithogenetic elements are restricted to single terranes or shared by adjacent terranes (Jones et al., 1983) as 1llustrated later in this paper.

Terrane analyses are meant to be more empirical than previous methods of paleogeographic reconstructions that resulted in an embarrassing number of plate tectonic models for a given area. Nevertheless, the accretionary nature of an orogen is extremely complex and ambiguities can still arise. Single terranes may have amalgamated to form composite terranes that have shared part of their geologic history prior to accretion to the craton. The problem presented is thus to work backward in time from the present composite terrane to define amalgamation or accretionary boundaries. In practice, these sutured boundaries may be completely obscured by later cover sequences or, alternately, a cover sequence may be so disrupted by later fault movement (terrane dispersion) that previous continuity of a terrane cannot be assured. A1so different facies may be inferred but not proven to be part of the same 11thogenetic element (see Fyffe and P1cker111, 1986). However, any erected system of terranes may be modified in analogy to the 1ithostratigraphic classification to accommodate new information. For example, a selsmic survey may indicate whether a mapped fault is a major or minor feature.

\section{TERRANE ANALYSIS OF NEW BRUNSWICK}

Using the Lexicon computer file, the complete set of formal units for New Brunswick (approximately 200) has been compiled down to the formation level (Fig. 1). The units have been grouped into the tectonostratigraphic zones of New Brunswick (Fig. $2)$, and within those according to sedimentary groups and igneous suites. The presentation is in the style of a conventional range or correlation chart, with ages displayed vertically and units 1isted in the horizontal axis (the time scale is from Palmer, 1983). Detalled 11thologic descriptions of the units are provided in Volume 6 of the Lexicon.

The correlation chart provides a convenient visual representation of the spatial and temporal relationships of the 11thostratigraphic and 11thodemic units present within each tectonostratigraphic zone of New Brunswick as previously estabilshed by Ruitenberg et al. (1977). This chart can be readily analyzed in terms of terrane concepts to reconstruct the accretionary history of the region.

Documenting the timing of terrane docking and welding involves the recognition of: (1) overlap linkages where the same stratigraphic sequence depositionally overlies adjacent terranes; (2) provenance 1inkages whereby detritus deposited in a terrane has been derived from an adjacent terrane; (3) plutonic linkages in which a terrane boundary has been sealed by intrusive rocks; and (4) biogeographical linkages which are indicated by the presence of fauna or flora of the same province in adjacent terranes (Coney et al., 1980; Jones et al., 1983).

In principle, any orogen is 1ikely to have preand post-accretionary distinctions for a given event. In New Brunswick, the pre-accretionary 1ithogenetic elements are taken to be Late Precambrian to early Late Ordovician (1.e., preTaconian) in age and the post-accretionary elements to be late Late Ordoviclan and younger (see Ruitenberg et al., 1977; Williams and Hatcher, 1982). Linkage relationships between the various terranes and the cover sequences are summarized in Fig. 3.

Since the tectonostratigraphic zones of Ruitenberg et al. (1977) used in construction of the correlation charts were based on the distinctive nature of pre-Taconian stratigraphy, 11ttle modification was needed in applying terrane concepts to them. It was essentially a matter of designating a tectonostratigraphic zone either as a terrane or as a cover sequence (Fig. 2). New Brunswick terranes and cover sequences from the northwest to the southeast are herein referred to as (zone designations of Ruitenberg et al. are given in brackets): Matapedia Cover Sequence (Zone 1), E1mtree Terrane (Zone 2), Miramich1 Terrane (Zone 3), Fredericton Cover Sequence (Zone 4a), St. Cro1x Terrane (Zone 4a), Mascarene Terrane (Zone 4b), and Avalonian Terrane (Zone 5). 


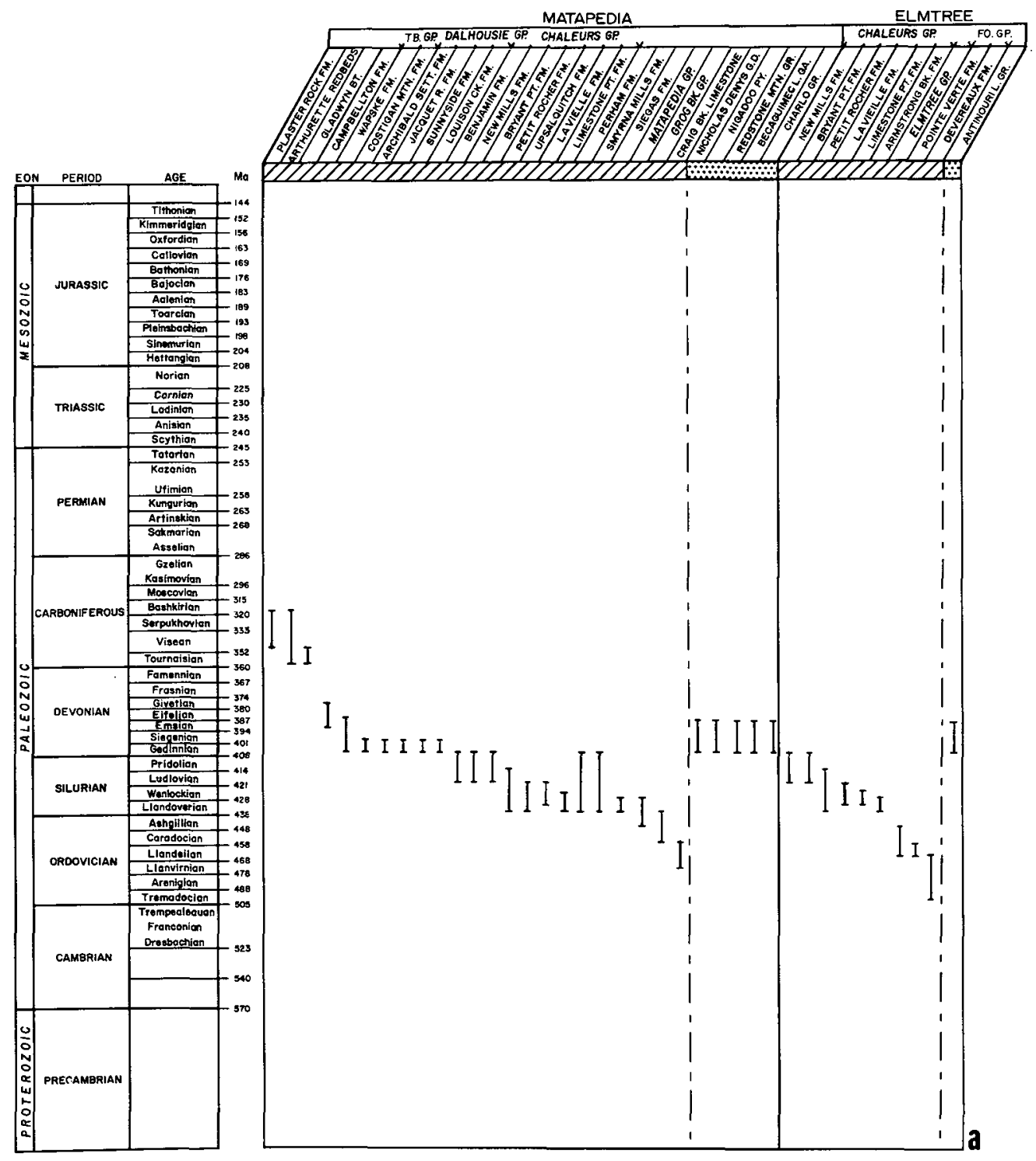

Fig. 1. Correlation Chart for Tectonostratigraphic Zones of New Brunswick: (a) Matapedia \& Elmtree; (b) Miramichi; (c) Fredericton \& St. Croix \& Mascarene; (d) Avalonian. The division of units between zones is discussed in the text. Ages of units are indicated by solid vertical range bars: vertical dashed bars outline the age range of groups containing unnamed formations. Solid vertical lines separate tectonostratigraphic zones. Hachured and dotted patterns on the horizontal bar located beneath unit names respectively separate lithostratigraphic and 1ithodemic terms within each zone. Ticks on the horizontal bar above unit names delineate formations within the named group. Abbreviations: BA - Batholith; BK - Brook; BT - Basalt; CG - Conglomerate; CK - Creek; CX - Complex; D - Diorite; DY - Dyke; FM - Formation; FO - Fournier; GA - Gabbro; GD - Granodiorite; GH - Green Head: GP - Group; GR - Granite; HT - Horton; INT - Intrusion; L - Lake; MT - Mount; MTN - Mounta1n; N - North; PC - Pet1tcodiac; PK - Park; PL - Pluton; PT - Point; PY - Porphyry; QD - Quartz Diorite; QM - Quartz Monzonite; R - RIver; RD - Road; S - South; SETT Settlement; SI - Sill; SK - Stock; SL - Slate; SM - Stream; ST - Salnt; TB - Tobique; TO - Tonalite; TR - Troctolite; VOL Volcanics: $W$ - West.

\section{Matapedia Cover Sequence}

The Matapedia Cover Sequence is no older than Late Ordovician (early Ashgilian) in the eastern Gaspé Peninsula (R1va, 1981) where it lies unconformably on Upper Cambrian platformal limestone of the Murphy Creek Formation (Rodgers, 1971). Any overlapping of the Matapedia sequence onto terranes in this region will thus give latest possible times of docking of these terranes (see below) to the North American platform during or after the Late Ordovician (F1g. 3). These accretionary events clearly must have occurred later than most of the
Ordovician (Caradocian) nappe emplacements (Vermontian phase of the Taconian orogeny, Rodgers, 1971) Into the foreland trough of the Quebec Applachians (St. Julien and Hubert, 1975).

\section{Elmtree Terrane}

The Stlurian Chaleurs Group, which conformably overlies the Upper Ordovician-Lower Silurian Matapedia Group, overstepped the ophiolitic Fournier Group of the E1mtree Terrane in the Early Silurian (late Llandoverian, Noble, 1976). The Jacquet River Fault (Figs. 2, 3) separates the 


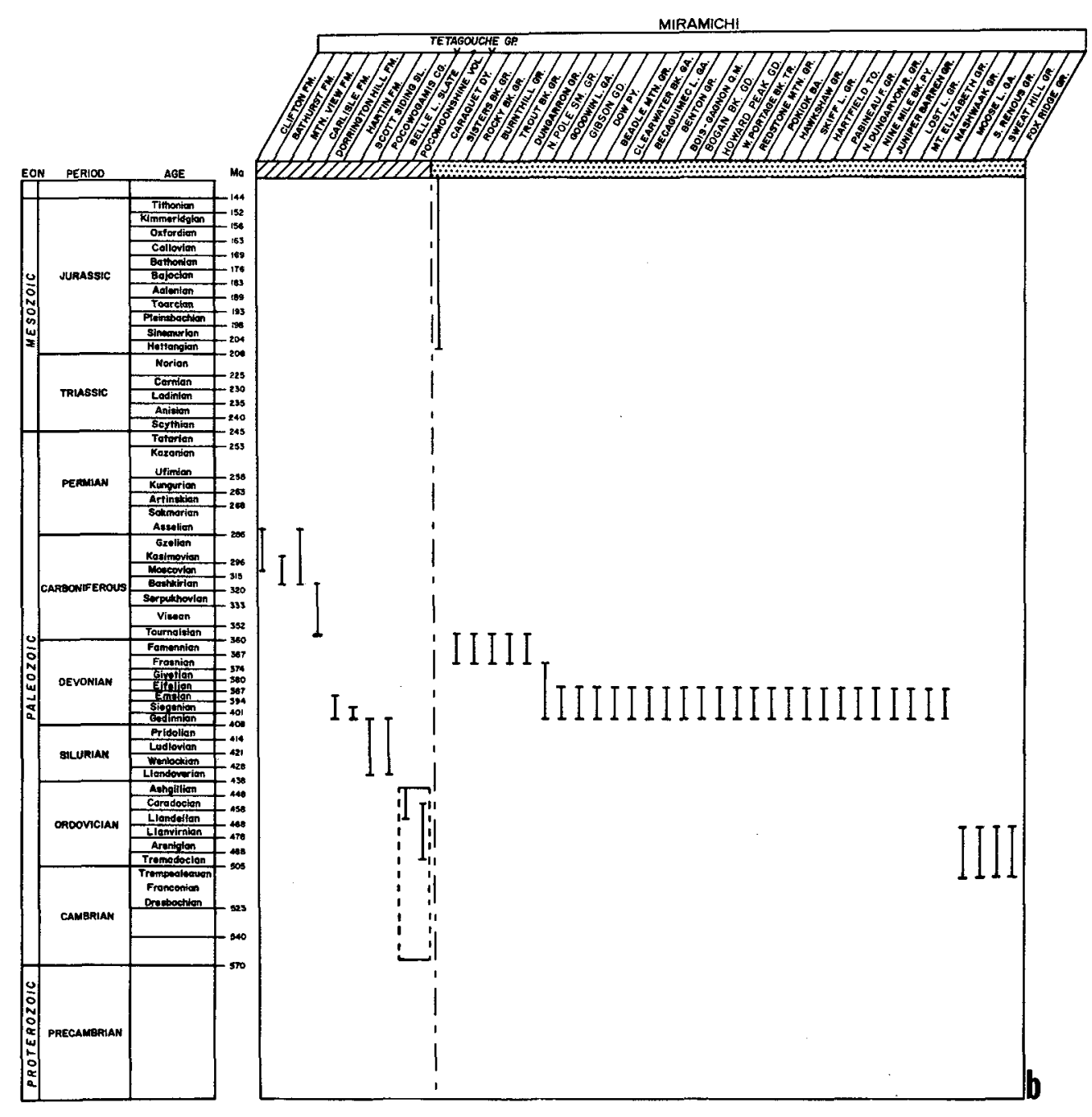

Fig. 1 Continued

shallower (In the east) and deeper water (in the west) facies of the Chaleurs Group. The Maquereau Terrane on the Gaspé shore of Chaleur Bay was also overlapped by the Chaleurs Group during the Early Silurlan (Ayrton, 1967). This reglonal unconformity delimits the Hudson Valley phase of the Taconian orogeny (Rodgers, 1971).

Although Silurlan cover rocks obscure the contact relationships between them, the 11thological similiarity of the Caradocian wackes of the Mictaw and E1mtree groups, respectively of the Maquereau and E1mtree terranes, may indicate that these two terranes were in close proximity during the Late Ordovician before being docked to the North American platform by the Early Silurian. The correlation of the Pointe Verte Formation of the Fournier Group with the upper part of the Tetagouche Group (Pajarl et al., 1977) would 1mp1y that the E1mtree and Miramichi terranes were also not widely separated in the Late Ordovician but such a correlation across the major Rocky BrookM111stream Fault needs to be viewed with caution.

\section{Miramicht Terrane}

Mid-Caradoctan and older rocks of the Miramich1
Terrane are in contact with the Matapedia Cover Sequence along the Rocky Brook-Millstream Fault in the northeast, and along the Portage Lakes, Serpentine River, and Woodstock faults in the west. The faults along the western margin have been Intruded by Barly Devonian gabbroic and granitic plutons that were locally mylonitized by reactivat1on of the faults (Fyffe and Cormier, 1979).

Some evidence exists that the Miramich 1 Terrane, or at least the northwestern extension of 1 , was docked (but not welded) to North America by the Late Ordovician. In the Woodstock area, in the southwestern part of the Matapedia Cover Sequence (F1g. 2), Upper Ordoviclan (upper Ashg1111an) conglomerate, presumably representing a shallow-water equivalent of the Matapedia Group, unconformably overlies a sma11 inller of Lower to lower Upper Ordovician (Llanvirian to lower Caradocian) Craig Brook LImestone with assoclated tuff and chert (St. Peter, 1982). This inlier, which occurs westward of the Woodstock Fault, has been correlated 11thologica11y with rocks in the nearby Tetagouche Group of the Miramicht Terrane (Fyffe et al., 1983) although volcanic rocks are not nearly as abundant. This implies that prior to the Late Ordovician, the Miramich1 Terrane included rocks presently under- 


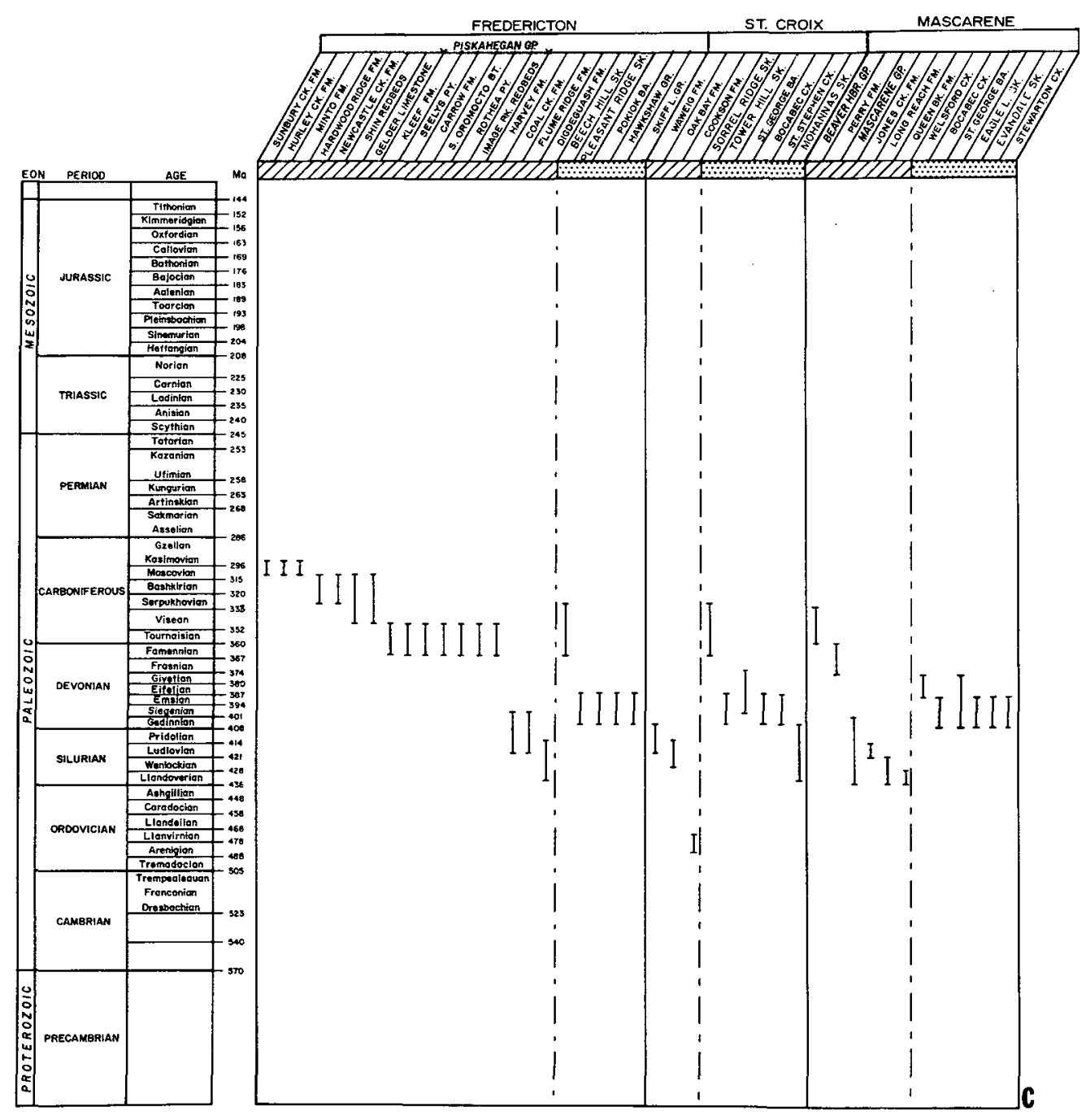

Fig. 1 Continued

1ying the southwestern portion of the Matapedia Cover Sequence, and furthermore must have been linked to the North American platform by the Late Ordovician. The Miramich1 Terrane may have extended in the subsurface as far to the northwest as the southwestern extension of the Rocky BrookMillstream Fault, which delimits the extent of shallow-water Late Ordovician to Early Devonian sedimentation in the area (FIg. 2).

Unfaulted relationships between the exposed main be1t of the Miramich1 Terrane and Matapedia Cover Sequence are preserved in a few localities. On the northwestern margin of the Miramich1 Terrane in the Portage Lakes area, Upper Silurian (Ludlovian) conglomerate of the Chaleurs Group overlies and contains clasts of lower Caradocian basalt of the upper part of the Tetagouche Group (Helmstaedt, 1971). In the Woodstock area to the southwest (Fig. 2), Lower Devonian sandstone of the Hartin Formation conformably overlies a calcareous conglomerate resting on Cambrian quartzite of the lower Tetagouche Group (Lutes, 1979). Deposition of some conglomerate (Pocowogamis Conglomerate) in this area was accompanied by faulting (Venugopal, 1979). Brachiopods in the Hartin Formation belong to the Appalachian Province (see Venugopal, 1979) as do those on the western margin of the Matapedia Cover Sequence (Boucot and Johnson, 1967).

Uplift of the Miramichl Terrane in the Late Silurian took place along faults of the Portage Lakes-Serpentine River, Woodstock, and Rocky BrookMi11stream systems (Rast and Stringer, 1974; Fyffe and Cormier, 1979), and was probably accompanied by considerable dextral displacement (Webb, 1969). This uplift is reflected not only by marginal unconformities but also internally within the Matapedia Cover Sequence by the widespread deposition of the Upper Silurian New Mills conglomerate (Greiner, 1967), and possibly by a local unconformity which separates the Lower Silurian Limestone Point Formation (late Llandoverian) from Upper Silurian (Pridolian) 1imy siltstone on Chaleur Bay (Fyffe and Noble, 1985). This period of uplift in northern New Brunswick has been referred to as the Salinic disturbance (Boucot, 1968).

Faults mapped by St. Peter (1982) in the Craig Brook area are compatible with a transcurrent component of motion along the northwestern margin of the Miramich1 Terrane. Dispersion of the Miramich1 Terrane along these faults would explain the 


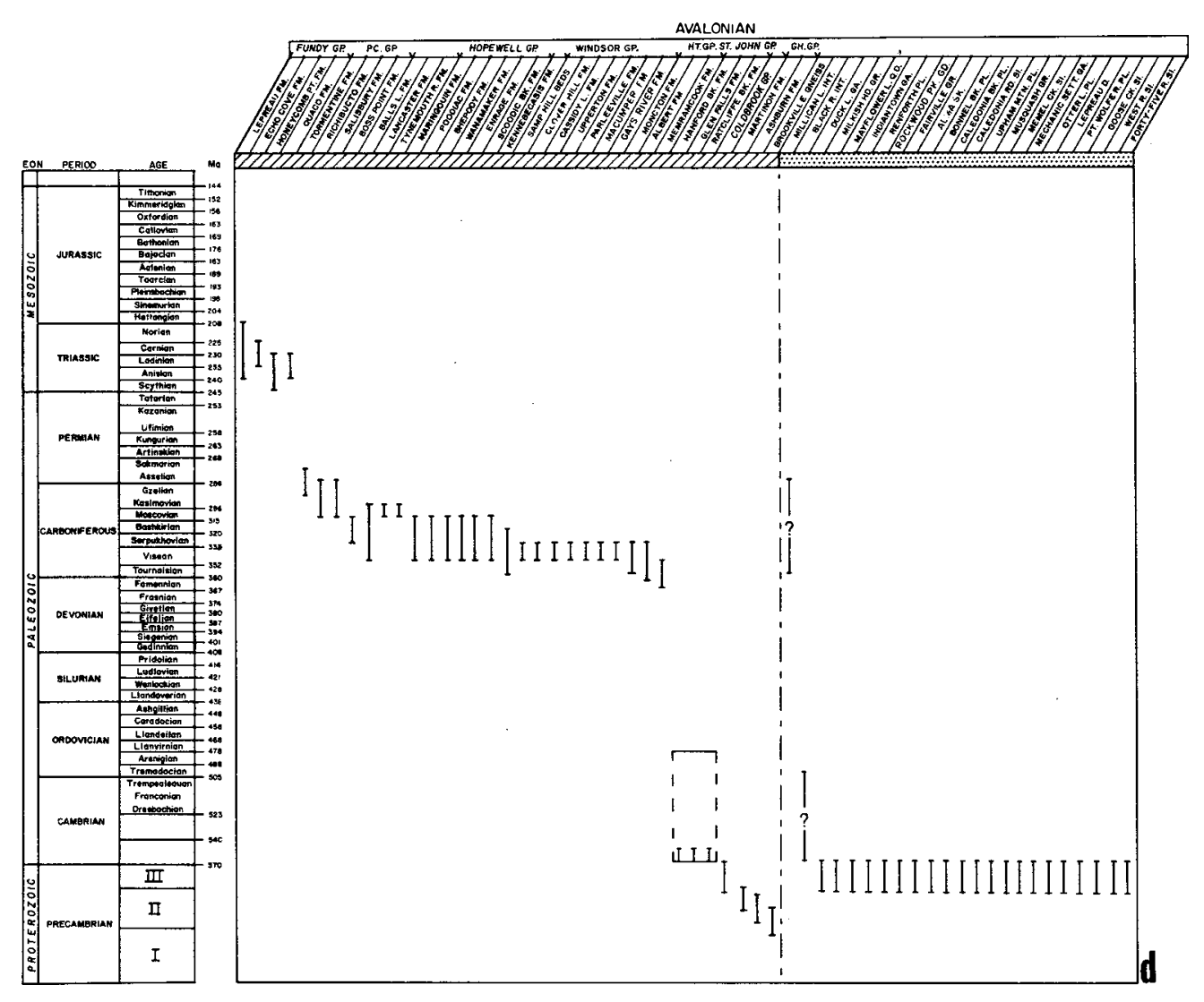

Fig. 1 Continued

observed facies differences between the Craig Brook inlier and the main belt of the Miramich1 Terrane. Furthermore, this dispersion may account for the pre-cleavage folding observed within the Matapedia Group. These folds occur both in the Matapedia Group of southwestern New Brunswick (Rast et al., 1980), and in the Lower Silurian Limestone Point Formation of northern New Brunswick (Stringer, 1975).

\section{Fredericton Cover Sequence}

The Fredericton Fault, which bisects the Fredericton Cover Sequence, is assumed to mark the boundary between the Miramichl and St. Croix terranes since it has been shown to be a major feature that may separate distinct Precambrian blocks in Maine (see Zen, 1983). The 11thological similarity of the cover rocks on opposite sides of this fault indicates that the Miramichi and St. Crolx terranes were docked (but not welded) prior to the Silurlan (Ludman, 1986). This contrasts with the interpretation of Kepple (In Kepple et al., 1985) who implies a difference in the cover rocks across the fault.

Furthermore, the 1ithological similarity of the lower Tetagouche Group of the Miramichi Terrane to that of the Cookson Formation of the St. Crolx Terrane in southwestern New Brunswick led Rast and Stringer (1974) to suggest continuity of deposition between these terranes during the Early Ordovician. Later stratigraphic studies and graptolite discoverles within the Miramichi Terrane have been used to support this view (Fyffe et al., 1983). The
Implication is that the docking of the two terranes took place before the Early Ordovician although the boundary did not become welded until late in the Carboniferous. Future selsmic, paleomagnetic and 1sotopic studies should provide evidence whether the Fredericton Fault actually represents a terrane boundary or merely marks a dispersal site of a once continuous terrane.

Graptolites recovered from the clastic turbidites of the cover sequence range in age from early Llandoverian to Ludlovian. The Miramicht Terrane is in contact with these Silurian rocks along the Bamford Brook-Hainesville Fault (O'Brien, 1977; Irrinki, 1980). This fault has been intruded by the granitic, late Early Devonian Pok1ok Batholith; later movement on the fault has fractured the granite (0'Brien, 1977; Venugopal, 1982).

Evidence that these Silurian rocks were cover to the Miramich1 Terrane is found within Upper Silurian (Wenlockian to Ludlovian) 1ithic wackes located along the faulted southeastern margin of the Miramichi Terrane. The wackes contain distinctive clasts of spherulitic volcanic rocks that can be matched with exposures of p1llow basalt within the adjacent Tetagouche Group of the Miramich1 Terrane (Irrink1, 1979). The Bamford BrookHainesville Fault, therefore, was not a locus of significant terrane dispersion in the latter part of the Silurian.

\section{St. Cro1x Terrane}

The oldest rocks known within the St. Croix Terrane are Lower Ordovician (Tremadocian- 


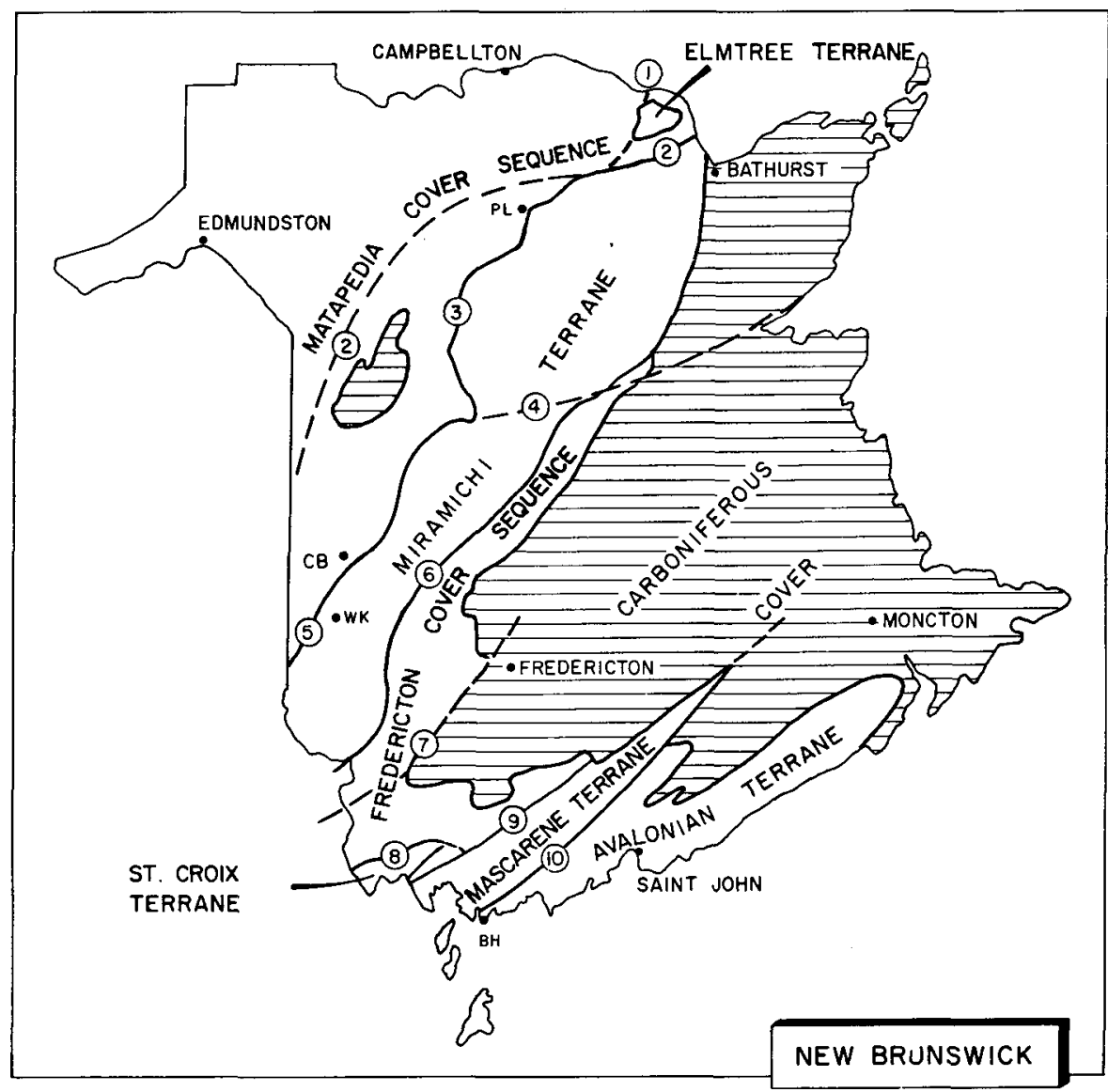

Fig. 2. Tectonostratigraphic terranes and cover sequences of New Brunswick. 1 - Jacquet River Fault; 2 - Rocky Brook-Millstream Fault: 3 - Portage Lakes-Serpentine River Fault; 4 - Catamaran Fault; 5 - Woodstock Fault; 6 - Bamford Brook-Hainesville Fault; 7 - Fredericton Fault; 8 - Honeydale Fault; 9 - Pendar Brook Fault; 10 - Belleisle Fault. Dashed lines represent faults within the cover sequences. Abbreviations: PL - Portage Lakes; WK - Woodstock; BH - Blacks Harbour; CB - Craig Brook.

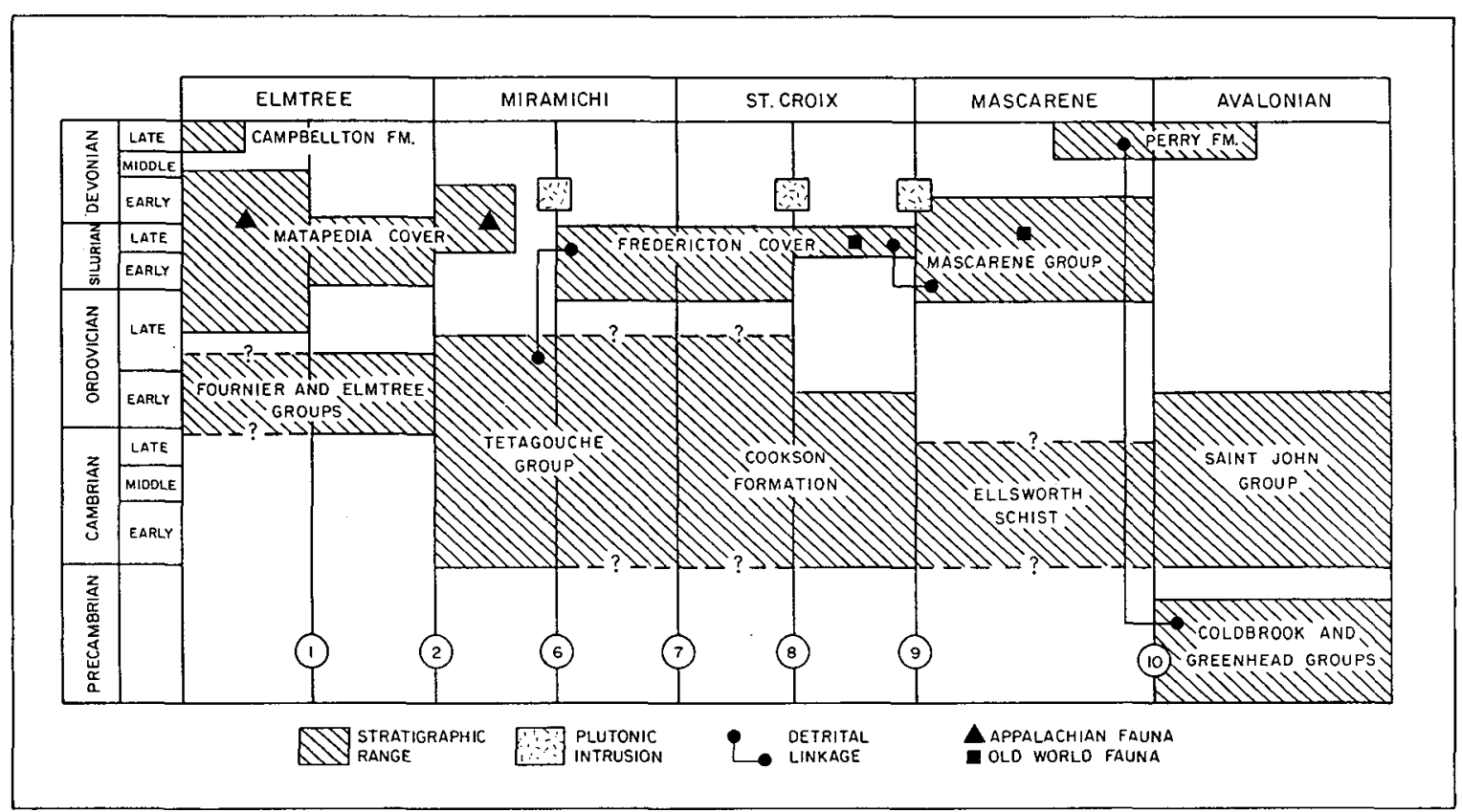

Fig. 3. Stratigraphic, detrital and plutonic linkages across terrane boundaries in New Brunswick. Numbers refer to faults 1isted in Fig. 2. Stratigraphic columns represent a composite section drawn between Campbeliton and Bathurst in the north and Woodstock and Saint John in the south. 
Arenigian) black slates, quartzites and minor basalt of the Cookson Formation (Cumming, 1967; Ruitenberg, 1967). These rocks were intensely deformed during the Taconian orogeny (Stringer and Burke, 1985), and are unconformably overlatn by conglomerate of the Upper Silurian Oak Bay Formation and sandstone of the Waweig Formation containing a shallow-water fauna (P1cker111, 1976). This unconformity cannot be solely attributed to the Taconian Orogeny, however, since Silurian limestone clasts occur in the Oak Bay Formation (Cumming, 1967; Pajar1, 1976). Uplift producing the conglomerate is, therefore, 11ke1y related to the Salinic disturbance (A. Ludman, written communication, 1986).

The Honeydale Fault separates the Cookson Formation and its shallow-water Silurian cover from the deep-water 11thic and quartzose turbidites (Digdeguash Formation) of the Fredericton Cover Sequence to the north. No fossils have been recovered from these turbidites in southern New Brunswick, but they are assumed to be Silurian by comparison to similiar lower Liandoverian to Ludlovian rocks north of the Fredericton Fault. A1though the Oak Bay, Wawe1g and Digdeguash formations apparent1y represent shallow- and deep-water facles of the same cover sequence (Ruitenberg. 1967). some terrane dispersion must have occurred since the two facies have been disrupted by movement on the Honeydale Fault. The late Ear1y Devonian Pocomoonshine pluton intrudes the Honeydale Fault in Maine and provides an upper limit to the time of this dispersion (Ruitenberg and Ludman, 1978). The eastern extension of the fault is difficult to trace because of poor exposure but it is presumably truncated by the late Early Devonian Saint George Batholith.

\section{Mascarene Terrane}

No pre-Silurian rocks are exposed in the Mascarene Terrane of New Brunswick but the Cambrian E11sworth Schist unconformably underlies the same Silurian and Lower Devonian volcanic rocks along strike in Maine (Stewart and Wones, 1974). The hiatus noted in Maine covers the same time interval as the unconformity in the St. Croix Terrane. Although this coeval hiatus may indicate that the Mascarene and St. Croix terranes were not widely separated, there is no evidence that they were actually docked with each other in the early Paleozoic. Brachiopods from the upper part of the Mascarene Group in New Brunswick and equivalents in Malne belong to the Early Devonian 01d World Province (Boucot and Johnson, 1967).

The Saint George Bathollth seals the Pendar Brook Fault, which forms the boundary between the Mascarene and St. Croix terranes in New Brunswick (McCutcheon, 1981), so that the two terranes were welded by the Early Devonian. Earlier docking is supported by two 11nes of evidence. The Silurian Oak Bay Formation of the St. Croix Terrane contains quartzite pebbles eroded locally from the underlying Ordovician Cookson Formation, as well as abundant volcanic clasts (Cuming, 1967) most 1ike1y derived from the Mascarene Terrane. Additiona11s, the Waweig Formation, which conformably overlies the Oak Bay Formation, possesses a Late Silurian brachiopod fauna similar to that in the Mascarene Group (P1ckeri11, 1976).
Avalontan Terrane

The boundary between the Mascarene and Avalonian terranes is defined by the Belleisle Fault (including the Wheaton Brook splay) to the northwest of which no rocks of Avalonian aspect are exposed (Brown and Helmstaedt, 1970; McCutcheon, 1981). Welding of these two terranes was not accomplished until after the Early Carboniferous since strata of that age are affected by movement on the Belleisle Fault (Webb, 1969; Brown and Helmstaedt, 1970).

The most direct line of evidence of linkage between the two terranes is provided by the Upper Devonian Perry Formation that unconformably overlies rocks of the Silurian to Lower Devonian Mascarene Group in the Blacks Harbour area (Fig. 2). The Perry possesses a main paleocurrent direction from the south and contains hornblende- and pyroxene-bearing plutonic pebbles that are similiar to intrusive rocks within the Avalonian Terrane; red granite clasts were derived from the Saint George Batholith, which intrudes the Mascarene Terrane (Schluger, 1976). The similiarity of Late S1lurian-Early Devonian 01d World faunal communities within the Mascarene Terrane of New Brunswick and Avalonian Terrane of Nova Scotia (Watkins and Boucot, 1975) is compatible with, but does not prove an earlier time of docking.

\section{SUMMARY AND CONCLUSIONS}

Stratigraphic evidence presented above suggests that terrane accretion had begun in northern New Brunswick by the Late Ordovician. Between the Late Ordovician and Early Silurian these terranes (Macquereau, E1mtree and Miramich1 terranes) had docked with the North American craton as indicated by the deposition of the Matapedia overlap sequence. This Taconian accretion apparently took place along a consuming plate margin by obduction of the Fournier ophiolite over the Tetagouche volcanic sequence. The Upper Silurlan-Lower Devonian rocks which form the conformable upper part of the overlap sequence on these terranes contain an Appalachian brachiopod assemblage.

The St. Crolx and Miramich1 terranes display similar early Paleozolc stratigraphy and structural histories. Therefore, if the Fredericton Fault is a terrane boundary separating different Precambrian basements, it was more 11kely the locus of alongstrike rather than across-strike displacement during the early Paleozolc. The Fredericton Fault was active during the late Paleozolc since it displaces Silurian rocks of the Fredericton Cover Sequence and overlying Carboniferous rocks.

The Mascarene Terrane may also have been proximal to North America by the early Paleozolc as it exhibits the affects of Taconian uplift in Maine. However, the Mascarene Terrane probably did not reach 1ts present position with respect to the St. Croix Terrane unt11 later in the Silurian when it shed detritus to the Oak Bay Conglomerate. Movement along the Pendar Brook Fault on the northern margin of the Mascarene Terrane had ceased by the Devonian as demonstrated by the intrusion of undeformed plutons.

The Avalontan Terrane need not have been widely separated from the Mascarene Terrane in the Late Silurian since both carry an 0ld World fauna. 
However, juxtaposition cannot be proven before the Late Devonian. Movement on the Belleisle Fault continued for a considerably longer time than on the Pendar Brook Fault as there is evidence for Early Carbontferous dextral displacement (Webb, 1969).

The Late Silurian accretion of the Mascarene Terrane in southern New Brunswick colncided with uplift along the northwestern boundary of the Miramichi Terrane at which time coarse clastic sediments were being deposited within the Matapedia Cover Sequence. The Salinic disturbance, thus, appears to have sporadically affected the New Brunswick Appalachlans throughout the area north of the Pendar Brook Fault. M1nor movement occurred on the Catamaran and Rocky Brook-M11lstream faults in northern New Brunswick as late as the Ear1y Carboniferous (Webb, 1969)

Laurent and Bélanger (1984) suggested that Siluro-Devonian volcanism in the region was generated in a transpressive intraplate tectonic environment rather than by subduction as postulated by McKerrow and Zlegler (1971). Therefore, Acadian accretion of the Mascarene and Avalonian terranes of southern New Brunswick can reasonably be attributed to a transcurrent regime as proposed by Zen (1983) and Zen et al. (1986). Later Variscan accretion in the New Brunswick Appalachians occurred along the Bay of Fundy fault system where dextra1 movement juxtaposed the Meguma Terrane of Nova Scotia with the Avalonian Terrane (Nance and Warner, 1986).

\section{ACKNOWLEDGEMENTS}

The authors would 11ke to thank A1 Ludman. Steve McCutcheon, Dave Stewart and E-an Zen for discussions on the geology of Maine and southern New Brunswick. Doug Cant, Glen Stockmal and Graham Williams offered useful comments on preliminary versions of the paper. Terry Leonard and Robin Wyllie drafted the figures and Diane Blatr typed the manuscript.

AYRTON, W.G. 1967. Chandler-Port-Daniel area, Bonaventure and Gaspé-South counties. Quebec Department of Natural Resources. Geological Report 120, 91 p.

BOUCOT. A.J. 1968. Silurian and Devonian of the northern Appalachians. In Studies of Appalachian Geology: Northern and Maritime. Edited by E-An Zen. W.S. White and J.B. Hadley. pp. 83-94.

BOUCOT. A.J. and JOHNSON, J.G. 1967. Appalach1an Province Barly Devonian paleogeography and brachiopod zonation. In International Symposium on the Devonian System. Edited by D.H. Oswald. Alberta Society of Petroleum Geologists, Calgary Alberta, 2. pp. 1255-1267.

BROWN, R.L. and HELMSTAEDT, H. 1970. Deformation history in part of the Lubec-Belle1sle zone of southern New Brunswick. Canadian Journal of Earth Sciences, 7, pp. 748-767.

CONEY, P.J. . JONES, D.L. and MONGER. J.W.H. 1980. Cordilleran suspect terranes. Nature, 288, pp. 329-333.

CUMMING, L.M. 1967. Geology of the Passamaquoddy Bay region, Charlotte County. New Brunswick. Geological Survey of Canada. Paper 65-29, 36 p.

FYFFB, L.R. and CORMIER, R.F. 1979. The slgntflcance of rad10metric ages from the Gulquac Lake area of New Brunsw1ck. Canadian Journal of Earth Sciences. 16. pp. 2046-2052.

FYFFB, L.R. and NOBLB, J.P.A. 1985. Stratigraphy and structure of the Ordovician, Silurian and Devonian of northern New Brunswick. In Field Guide, Excursion 4. Geological Association of Canada. Mineralogical Association of Canada, Fredericton. New Brunswick, 2. pp. 1-56.

FYFFE, L.R. and PICKERILL. R.K. 1986. Comment on "TIming of terrane accretion in eastern and east-central Maine." Geology. 15. pp. 1051-1052.
FYFFE, L.R. , FORBES, W.H. and RIVA, J. 1983. Graptolites from the Benton area of west-central New Brunswick and their regional significance. Marltime Sediments and Atlantic Geology. 19. pp. 117-125.

Geology, 19. Pp. 117-125.
GREINER, H.R. 1967. S1lurian-Devonain relationships, Char10 map area. New Brunswick. International Symposium on the Devonian System. Edited by D.H. Oswald. Alberta Society of Petroleum Geolog1sts, Calgary, Alberta, 2, pp. 973-979.

HELMSTAEDT, H. 1971. Structural geology of Portage Lakes area. Bathurst-Newcastle distr1ct, New Brunsw1ck. Geological Survey of Canada, Paper 70-28, 52 p.

IRRINKI, R.R. 1979. Geology of North and South Little Sevogle Rivers-North Branch, Little Southwest Miramich1 RiverMcKendrick and Catamaran lakes region (map-areas 0-12, N-12. and N-13). Mineral Resources Branch. New Brunswick Department of Natural Resources. Map Report 79-1. $36 \mathrm{p}$.

IRRINKI, R.R. 1980. Geology of Kennedy Lakes-L1ttle Dungarvon and South Renous rivers region (map-areas $M-13, M-14, M-15$ and Part of M-16). Mineral Resources Branch, New Brunswick Department of Natural Resources, Map Report $80-2,39$ p.

JONES, D.L. , HOWELL, D.G., CONEY, P.J. and MONGER, J.W.H. 1983. Recognition, character and analysis of tectonostratigraphic terranes in western North America. In Accretion Tectonics in the Circum-Pacific Regions, Advances in Earth and Planetary Sclences. Edited by M. Hashimoto and S. Vyeda. D. Re1dal Publishing Company. New York, pp. 21-35.

KEPPIE, J.D.. CURRIE, K., MURPHY, J.B. . PICKERILL, R.K. , FYFFE, L.R and ST-JULIEN P. 1985. Appalachian Geotraverse (Canadian Malnland). Fleld Guide, Excursion 1. Geological Association of Canada. Mineralogical Association of Canada, Fredericton, New Brunswick, $181 \mathrm{p}$.

LAURENT, R. and BELANGER. J. 1984. Geochemistry of S1lurianDevonian alkaline basalt sultes from the Gaspé Peninsula, Quebec Appalachians. Maritime Sediments and Atlantic Geology. 20. pp. 67-78.

LUDMAN, $A$. 1986. Timing of terrane accretion in eastern and east-central Ma1ne. Geology, 14. pp. 411-414.

LUTES, G. 1979. Geology of Fosterville-North and Ee1 lakes. map area G-23, and Canterbury-Skiff Lake, map area $\mathrm{H}-23$. Mineral Resources Branch, New Brunsw1ck Department of Natura1 Resources, Map Report 79-3. 22 p.

MCCUTCHEON, S.R. 1981. Revised stratigraphy of the Long Reach area, southern New Brunswick: Evidence for major, northwestward-directed Acadian thrusting. Canadian Journal of Earth Sciences, 18, pp. 646-656.

MCKERROW. W.S. and ZEIGLER, A.M. 1971. The Lower Silurian paleogeography of New Brunswick and adjacent areas. The Journal of Geology. 79, pp. 635-646.

NANCE, R.D. and WARNER, J.B. 1986. Variscan tectonostrat1graphy of the Mispec Group, southern New Brunswick: structural geometry and deformation history. In Current Research, Part A. Geological Survey of Canada, Paper 86-1A. pp. 351-358.

NOBLE, J.P.A. 1976. Silurian stratigraphy and paleogeography. Pointe Verte area, New Brunswick. Canada. Canadian Journal of Earth Sclences, 13. pp. 537-546.

O'BRIEN. B.H. 1977. Pre-Acadian deformation, metamorph1sm, and intrusion in the vicinity of the Pokiok pluton. west-central New Brunswick and its regional implications. Canadian Journal of Earth Sciences. 14, pp. 1796-1808.

PAIMER, A.R. 1983. The decade of North American geology. geologic time scale. Geology. 11. pp. 503-508.

PAJARI. G.E. JR. editor. 1976. Igneous rocks of southwestern New Brunswick. In Field guide to the geology and plutonic rocks of southwestern New Brunswick and the Penobscot Bay area of Ma1ne. I.G.C.P. Canadian Plutonics Study group. Project Caledonide Orogen. Capital Free Press, Fredericton. New Brunswick, pp. 1-7.

PAJARI, G.E. JR, RAST, N. and STRINGER, P. 1977. Paleozo1c volcanicity along the Bathurst-Dalhousle geotraverse, New Brunswick, and its relations to structure. In Volcanic Regimes in Canada. Edited by W.R.A. Baragar, L.C. Coleman, and J.M. Hall. Geological Association of Canada, Special Paper 16, pp. 111-124.

PICKERILL, R.K. 1976. Significance of a new fossil locality containing a Salopina Community in the Waweig Formation (S1lur1an-uppermost Ludlow/Pr1do11) of southwest New Brunswick. Canadian Journal of Earth Sclences, 13, pp. 13281331.

RAST, N. and STRINGER P. 1974. Recent advances in the interpretation of geological structure of New Brunswick. Geoscience Canada, 2. pp. 15-25.

RAST, N. . LUTES, G.G. and ST. PETER, C. 1980. The geology and deformation history of the southern part of the Matapedia zone and 1ts relationsh1p to the Miramich1 zone and Canterbury basin. In A guidebook to: The Geology of Northeastern Maine and Neighboring New Brunswick. Edited by D.C. Roy and R.S. 
Naylor. 72nd Annual Meeting of the New England Intercollegiate Geological Conference, pp. 191-201.

RIVA, J. 1981. Graptolites from the Matapédia and Honorat groups of Gaspé. In IUGS Subcomnission on Silurian Stratigraphy, Ordovician-Silurian Boundary Working Group; Field Meeting. Edited by P.J. Lespérance. Stratigraphy and Paleontology, Ant1cost1-Gaspé, Québec, 2. pp. 293-298.

RODGERS, J. 1971. The Taconic Orogeny. Geological Society of America Bulletin, 82, pp. 1141-1177.

RUITENBERG A.A. 1967. Stratigraphy, structure and metallization. P1skahegan-Rolling Dam area, northern Appalachians, New Brunswick, Canada. Le1dse Geolog1sche Mededelingen, 40, pp. 79-120.

RUITENBERG, A.A. and LUDMAN, A. 1978. Stratigraphy and tectonic setting of Early Paleozolc sedimentary rocks of the Wirra1-Bis Lake area, southwestern New Brunswick and southeastern Maine. Canadian Journal of Earth Sclences, 15. pp. 22-32.

RUITENBERG, A.A., FYFFE, L.R., MCCUTCHEON, S.R., ST. PETER, C.J., IRRINKI, R.R. and VENUGOPAL. D.V. 1977. Evolution of pre-Carboniferous tectonostratigraphic zones in the New Brunsw1ck Appalachians. Geoscience Canada, 4. pp. 171-181.

ST. JULIEN, P. and HUBERT, C. 1975. Evolution of the Taconian Orogen in the Quebec Appalachians. American Journal of Science, 275-A, pp. 337-362.

ST. PETER, C. 1982. Geology of Juniper-Knowlesville-Car1isle area, New Brunswick. Mineral Resources Branch, New Brunswick Department of Natural Resources, Map Report 82-1, $82 \mathrm{p}$.

SCHLUGER, P.R. 1976. Petrology and origin of the red beds of the Perry Formation, New Brunswick, Canada and Maine, United States of America. Journal of Sedimentary Petrology, 46, pp. 22-37.

SPENCER, A.M. editor. 1974. Mesozoic-Cenozo1c orogenic belts. The Geological Society, London, Special Publication 4. Scott1sh Academic Press, Edinburgh, 809 p.

STEWART, D.B. and WONES, D.R. 1974. Bedrock geology of northern Penobscot Bay area. In New England Intercollegiate Geological Conference Guidebook. 66th Annual Meeting. Edited by P.H. Osberg. University of Maine, Orono, Maine, pp. 223239.
STRINGER, P. 1975. Acadian slaty cleavage noncoplanar with fold axial surfaces in the northern Appalachians. Canadian Journal of Earth Sc1ences. 12, pp. 949-961.

STRINGER, P. and BURKE. K.B.S. 1985. Structure in southwest New Brunswick. In Field Guide, Excursion 9. Geological Association of Canada. Mineralogical Association of Canada. University of New Brunswick. Fredericton. New Brunswick, 34 p.

VENUGOPAL, D.V. 1979. Geology of Debec Junction-Gibson Mi11stream-Temperance Vale-Meductic region (map-areas G-21, H-21. I-21, H-22). Mineral Resources Branch, New Brunswick Department of Natural Resources. Map Report 79-5, $36 \mathrm{p}$.

VENUGOPAL, D.V. 1982. Geology of upper parts Becaguimec, Keswick, and Nashwaak Rivers, Cloverdale-Millville, map areas I-19, J-19. J-20. Mineral Resources Branch, New Brunswick Department of Natural Resources, Map Report 82-2, 35 p.

WATKINS R. and BOUCOT. A.J. 1975. Evolution of S1lurian brachiopod communities along the southeastern coast of Acadia. Geological Society of America Bulletin, 86, pp. 243-254.

WEBB, G.W. 1969. Paleozo1c wrench faults in Canadian Appalachians. In North Atlantic Geology and Continental Drift. Edited by M. Kay. American Association of Petroleum Geologists, Memoir 12, pp. 754-786.

WILLIAMS, G.L., FYFFE, L.R., WARDLE, R.J., COLEMAN-SADD, S.P. and BOEHNER, R.C., editors. 1985. Lexicon of Canadian stratigraphy, Volume VI, Atlantic region. Canadian Society of Petroleum Geologists, Calgary, Alberta, Canada, 572 p.

WILLIAMS, H. 1979. Appalachian orogen in Canada. Canadian Journal of Earth Sciences, 16, pp. 792-807.

WILLIAMS, H. and HATCHER, R.D. 1982 . Suspect terranes and accretionary history of the Appalachian orogen. Geology, 10, pp. 530-536.

ZEN, E-an. 1983. Exutic terranes in the New England Appalachians - limits, candidates, and ages: a speculative essay. Geological Society of America, Memoir 158, pp. 55-81.

ZEN, E-an, STEWART, D.B. and FYFFE, L.R. 1986. Paleozolc tectonostratigraphy terranes and their boundaries in the mainland northern Appalachians. 99th Annual Meet1ng and Expos1tion. Geological Society of America, San Antonio, Texas, Abstracts with Programs, p. 800 